REVIJA ZA ELEMENTARNO IZOBRAŽEVANJE
JOURNAL OF ELEMNTARY EDUCATION

Vol. 13, No. 2, pp. 215-242, Junij 2020

\title{
PouČEVANJE SPOZNAVANJA OKOLJA IN \\ NARAVOSLOVNI KAPITAL UČENCEV
}

VASJA KOŽUH

Potrjeno/Accepted

23. 12.2019

Objavljeno/Published

8. 6.2020

Ključne besede:

spoznavanje okolja, naravoslovno znanje, spoznavni procesi in postopki,

oblike poučevanja, ocenjevanje znanja.

\section{Keywords: natural} science, scientific knowledge, scientific skills,

methods of teaching assessment of knowledge

UDK/UDC: 373.3.091.3:5
Univerza na Primorskem, Pedagoška fakulteta in Založba DZS, Slovenija

KORESPONDENČNI AVTOR/CORRESPONDING AUTHOR

vasja.kozuh@siol.net

Izvleček/Abstract $V$ prispevku predstavljamo potek in rezultate raziskave, katere osnovni namen je podrobneje spoznati poučevanja učnega predmeta spoznavanje okolja. Ugotovili smo, da učiteljice $\mathrm{v}$ prvem vzgojnoizobraževalnem obdobju ocenjujejo, da so motivirane za delo in kompetentne za poučevanje predmeta spoznavanje okolja. Pri tem se čutijo manj pripravljene za poučevanje fizikalnih, kemijskih, tehniških, socioloških in psiholoških vsebin kot za poučevanje drugih vsebin. Nadalje ugotavljamo, da določene naravoslovne postopke, kot so analiza in interpretacija podatkov, raziskovanje in delo $\mathrm{z}$ računalniki, izvajajo manj pogosto od drugih postopkov. Pri vrednotenju znanja se opirajo predvsem na pisne in ustne odgovore učencev.

Teaching early science and pupil's natural science capital

This paper presents in detail the results of research in which the primary interest was teaching early science in the 1 st trimester of elementary school. It was concluded that, in terms of popularity, expressed by the teacher's own estimation of their competence to teach a specific course, the introduction to environmental science falls a little above average. With regard to the frequency of carrying out various activities, it was established that teachers employ the following activities less than others: connecting, interpreting, organising and analysing data by carrying out simple research and using ICT and e-learning. Teachers prefer to assess the students' knowledge with the evaluation method rather than with other assessment methods. 


\section{Uvod}

V drugi polovici prejšnjega stoletja je dozorelo spoznanje, da naravoslovno znanje ni zgolj domena inženirjev in znanstvenikov, temveč ga mora $\mathrm{v}$ določeni meri imeti vsak posameznik, če se želi uspešno spopadati z izzivi sodobnega časa. Ob tem se je začelo vse bolj poudarjati, da je znanje mnogo več kot le poznavanje in razumevanje določenih dejstev in zakonitosti (Raper in Stinger, 1987; Harlen, 1992) ter da učenje poteka vse življenje in na vsakem koraku. Kljub razširitvi pojmovanja znanja (slika 1) in uvedbi določenih sprememb $v$ poučevanju so začeli znanstveniki ugotavljati, da to samo po sebi še ne zadošča za uspešno naravoslovno udejstvovanje posameznika v družbi. Zato so v 80 -ih in 90 -ih letih prejšnjega stoletja začeli govoriti o različnih vrstah pismenosti (slika 1), ki znanje postavljajo $v$ različne kontekste oziroma poleg znanja zajemajo tudi zmožnost in pripravljenost posameznika za aktivno udejstvovanje v družbi. Omenjeno je predstavljeno tudi v smernicah za izobraževanje v 21. stoletju, ki jih je pripravil Unesco (Delors in drugi, 1996). V zadnjih letih znanstveniki v Veliki Britaniji (Archer in drugi, 2014, 2015) ugotavljajo, da zmožnost in pripravljenost za naravoslovno udejstvovanje za dejansko udejstvovanje ne zadošča, temveč morajo biti posamezniku dostopni tudi viri znanja, do katerih mora znati dostopati in jih uporabljati. Zato raje kot o pismenosti govorijo o naravoslovnem kapitalu (slika1).

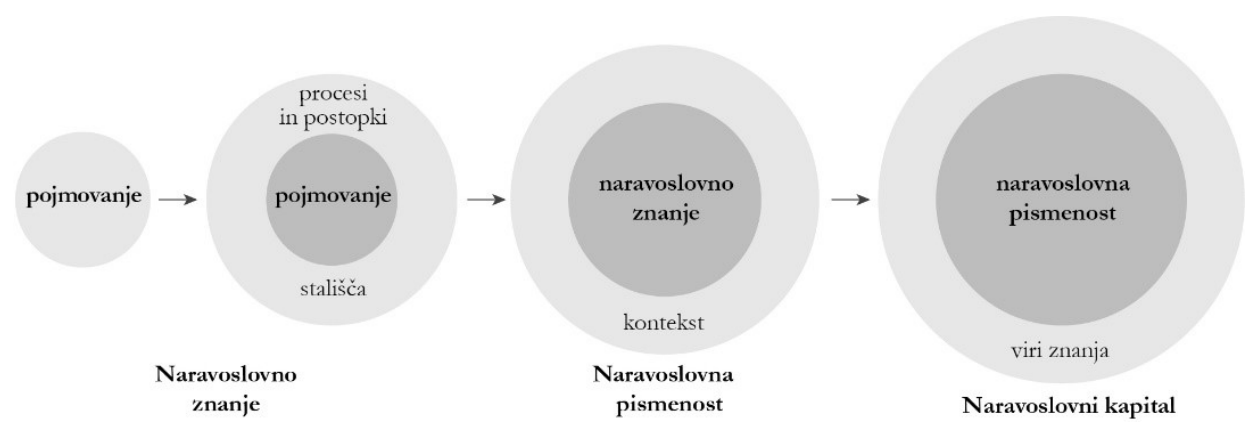

Slika 1: Shematski prikaz spreminjanja pojmovanja naravoslovnega znanja. 


\section{Teoretična izhodišča}

Naravoslovno znanje, naravoslovna pismenost in naravoslovni kapital

Današnje pojmovanje znanja je razvidno iz Unescove opredelitve učenja kot vsake pridobitve ali spremembe védenja, informiranosti, razumevanja, stališčc, spretnosti, zmožnosti ali vedênja, z izkustvom, vajo, s poučevanjem ali študijem (UNESCO, 2012). Naravoslovno znanje je najpogosteje opredeljeno kot preplet posameznikovega naravoslovnega pojmovanja (angl. concepts), spoznavnih procesov in postopkov (angl. skills) ter njegovih stališč (angl. attitudes) $\mathrm{v}$ povezavi z naravoslovjem (slika 2). Podrobnejše opredelitve se med avtorji nekoliko razlikujejo. Tako po Raper in Stinger (1991) naravoslovno pojmovanje tvorijo dejstva (poimenovanja, definicije, dogovori), zamisli (splošne zamisli, načela, znanstveni zakoni in teorije) in razumevanje. Harlen in Qualter (2009) spoznavne procese in postopke delita na raziskovalne, miselne, učne in sporočevalne (slika 2). Pri tem omenjata predvsem zastavljanje vprašanj, napovedovanje, načrtovanje zbiranja in zbiranje podatkov, analiziranje in interpretacijo podatkov, sporočanje, oblikovanje sklepov, razvrščanje, urejanje, primerjanje, prepoznavo vzorcev, reševanje problemov ter povzemanje. Glede naravoslovnih stališč je med avtorji največ razhajanj; mi se bomo oprli na Gardnerjevo (1975) delitev na odnos do naravoslovja (angl. attitudes towards science) in naravoslovne vrednote (angl. scientific attitudes). Odnos do naravoslovja zajema zanimanje za naravoslovje, naravnanost do naravoslovja, družbeno odgovornost na področju naravoslovja ipd.; naravoslovne vrednote pa radovednost, dojemljivost, intelektualno poštenost, preudarnost, skepso ipd.

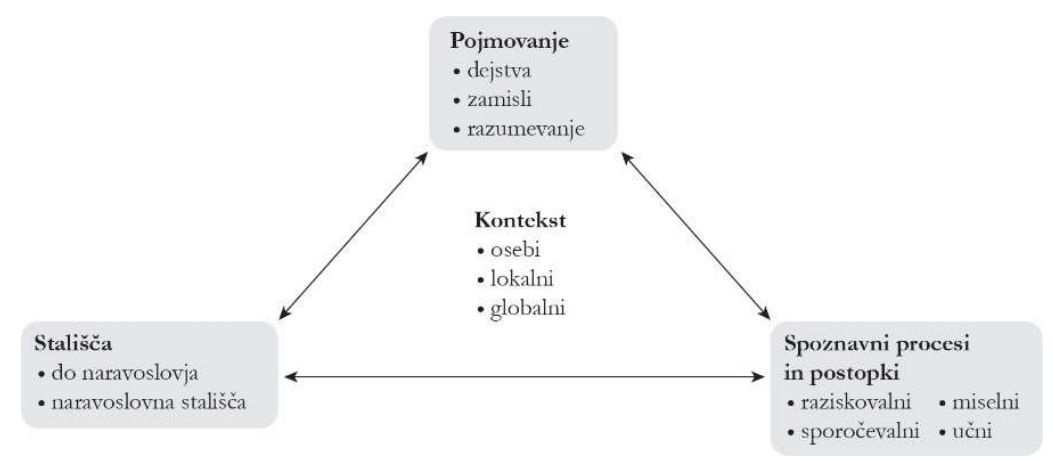

Slika 2: Shematski prikaz naravoslovnega znanja (Povzeto po Raper in Stinger, 1991, str. 11, nadgrajeno s Harlen in Qualter, 2009, Gardner, 1975 in OECD, 2017.) 
Z reformo poučevanja naravoslovja $v$ ZDA konec 80 -ih in $\mathrm{v}$ začetku 90 -ih se je namesto o naravoslovnem znanju začelo govoriti o naravoslovni pismenosti (Ruhterford in Ahlgren, 1991). Naravoslovno pismenost, ki v svojem jedru zajema naravoslovno znanje, lahko razumemo kot zmožnost uporabe naravoslovnega znanja, informacij in procesov za razumevanje sveta okoli sebe, zmožnost in pripravljenost vključevanja $\mathrm{v}$ argumentirane razprave ter sodelovanja $\mathrm{v}$ odločitvah, ki zajemajo naravoslovno tematiko. Organizacija za gospodarsko sodelovanje in razvoj (OECD, 2017) posredno opredeljuje naravoslovno pismenost s področji preverjanja v raziskavi PISA 2015, ki so: kontekst, znanje, kompetence (spoznavni procesi in postopki) in stališča, pri čemer kontekst deli na osebni, lokalni in globalni (slika 2), znanje pa na vsebinsko, procesno in epistemološko. Nedavne raziskave v Veliki Britaniji o naravoslovnem udejstvovanju odraslih (Archer in drugi, 2014, 2015) so pokazale, da naravoslovna pismenost ni najbolj zanesljiv napovednik aktivnega družbenega udejstvovanja. Zato so po vzoru socialnega, kulturnega in ekonomskega kapitala kot napovednik »naravoslovne uspešnosti« posameznika uvedli t. i. naravoslovni kapital, ki vključuje naravoslovno znanje ter njegove izkušnje in vire znanja (slika 1). Sistematično učenje naravoslovnih vsebin oziroma gradnja znanstvenega kapitala se $\mathrm{v}$ Sloveniji začne $\mathrm{v}$ vrtcu in nadaljuje $\mathrm{v}$ prvem vzgojnoizobraževalnem obdobju v okviru predmeta spoznavanje okolja.

\section{Poǔ́evanje učnega predmeta spoznavanje okolja}

Poučevanje učnega predmeta spoznavanja okolja je izjemno zahtevno, saj učne vsebine izhajajo iz več kot desetih naravoslovnih in tehničnih (kemija, fizika, biologija, informatika, tehnika in tehnologija) ter družboslovnih (zgodovina, geografija, komunikologija, sociologija, psihologija, etnologija, ekonomija in politologija) znanstvenih ved. Temu so dodane še druge vsebine (prometna varnost, okoljska vzgoja, zdrav način življenja). Učitelji v prvem vzgojno-izobraževalnem obdobju morajo imeti kakovostno in poglobljeno znanje na vseh naštetih področjih ter poznati številne povezave med njimi, saj pri učnem predmetu spoznavanje okolja gradijo temelje naravoslovne pismenosti. Iz učnega načrta (Kolar in drugi, 2011) je razvidno, da temelji na konstruktivističnem pristopu. Ivanuš Grmek in sodelavci (2009) pri tem posebej poudarjajo lastno aktivnost učencev. Petek (2012) takšen pristop opredeljuje kot raziskovalno didaktični pouk, ki temelji na raziskovanju in reševanju problemov. Rajšp s sodelavci (2013) ob tem opozarja, da mora biti znanje $\mathrm{v}$ čim večji meri pridobljeno na osnovi lastnih izkušenj v neposrednem okolju. O 
pomembnosti uporabe različnih metod ocenjevanja znanja piše Skribe Dimec (2007).

Raziskave poučevanja naravoslovja in naravoslovnega z̦nanja učencev

V Sloveniji je bilo v zadnjih letih narejenih kar nekaj raziskav na področju zgodnjega poučevanja naravoslovja. Skribe Dimec (2013) ugotavlja, da je diferenciacija pouka premalo prisotna $\mathrm{v}$ učnem načrtu za predmet spoznavanje okolja ter pripadajočih učnih gradivih in učnih pripravah študentov razrednega pouka. Dolenc Orbanić in Furlan (2015) za študente razrednega pouka ugotavljata, da se ne čutijo dovolj usposobljeni za poučevanje naravoslovja in bi pri tem uporabljali predvsem tradicionalne učne pristope. Pevec (2012) v povezavi z nadaljnjim izobraževanjem in usposabljanjem učiteljev ugotavlja, da je po mnenju učiteljev kakovost tovrstnih izobraževanj v splošnem slaba, zato se jih učitelji le neradi udeležujejo. Podobno ugotavlja tudi Polak s sodelavci (2005). Ivanuš Grmek in sodelavci (2009) ugotavljajo, da ima projektni pouk velik vpliv na znanje in interes učencev. Cotič in sodelavci (2019) dokazujejo pozitivne vplive izkustvenega učenja v naravnem okolju ob hkratni uporabi IKT (informacijsko-komunikacijska tehnologija). Hkrati Rajšp in sodelavci (2013) ugotavljajo, da pouk spoznavanja okolja preredko poteka v naravnem okolju, za kar učitelji navajajo predvsem organizacijske in finančne težave. $\mathrm{V}$ povezavi z naravoslovnim znanjem učencev $\mathrm{v}$ prvem vzgojno-izobraževalnem obdobju Petek in Glažar (2015) ugotavljata, da je naravoslovno znanje učencev v starosti 7-9 let pomanjkljivo, predvsem to velja za sposobnosti sporočanja, napovedovanja in sklepanja ter zbiranja in urejanja informacij. Posebej zanimivi so izsledki mednarodne raziskave TIMSS 2015, v kateri se naši četrtošolci po znanju naravoslovja uvrščajo na 11. mesto med učenci 47 držav, udeleženk raziskave. Zadnjih 20 let je opazna tudi stalna težnja naraščanja dosežkov naših četrtošolcev v znanju naravoslovja (Pavešić in Svetlik, 2016). Podrobnejša analiza razkrije, da so naši četrtošolci v povprečju slabši pri sklepanju in imajo precej bolj odklonilna stališča do naravoslovja kot vrstniki iz večine držav udeleženk. Tudi njihovi starši izražajo odklonila stališča do naravoslovja. Omenjena raziskava pokaže še, da pri nas $41 \%$ četrtošolcev učijo učitelji z izobrazbo, ki ni univerzitetna (večinoma gre za diplomante bivših pedagoških akademij), kar je slabše od mednarodnega povprečja. Učitelji zaostajajo za mednarodnim povprečjem tudi pri strokovnem izpopolnjevanju. 


\section{Raziskovalni problem}

Glede na pomen poučevanja učnega predmeta spoznavanje okolja za razvoj naravoslovnega kapitala in splošnega spoznavnega razvoja učencev ter na ugotovljena odstopanja $\mathrm{v}$ naravoslovni pismenosti naših četrtošolcev, ki so jih pokazale raziskave (Petek in Glažar, 2015; Pavešić in Svetlik, 2016), se nam zdi potrebno raziskati razloge za nastale razmere in oblikovati predloge za njihovo izboljšanje. Ker učni načrt po naši presoji ni osnovni vir težav, smo se osredinili na učitelja in njegovo poučevanje. Zanima nas profil učitelja $v$ prvem vzgojnoizobraževalnem obdobju, v kolikšni meri sledi zahtevam in vsebinam učnega načrta, ali je ustrezno usposobljen in motiviran za delo, katere oblike ocenjevanje znanja uporablja in katere aktivnosti izvaja pri pouku. Pričakujemo namreč, da bodo odgovori na omenjena vprašanja razkrili stanje na področju poučevanja spoznavanja okolja in razloge zanj.

\section{Cilj raziskave}

Osnovni namen naše raziskave je natančneje preučiti poučevanja učnega predmeta spoznavanje okolja $\mathrm{v}$ prvem vzgojno-izobraževalnem obdobju. Ker splošna raziskava na tem področju po našem védenju pri nas še ni bila opravljena, raziskavo načrtujemo kolikor se da široko. $\mathrm{Na}$ osnovi izsledkov raziskave želimo določiti usmeritve za nadaljnje raziskave, s katerimi bi natančneje opredelili vzroke za ugotovljene razmere ter možnosti in predloge za izboljšave. Zato smo si zastavili naslednje raziskovalne cilje, in sicer ugotoviti:

- kakšen je profil učitelja prvega vzgojno-izobraževalnega obdobja;

- katere naravoslovne postopke vključujejo učitelji v pouk spoznavanja okolja in v kolikšni meri;

- katere vsebinske sklope iz učnega načrta učitelji najraje/najmanj radi poučujejo in

- katere oblike ocenjevanja znanja uporabljajo učitelji pri pouku spoznavanja okolja in v kolikšni meri. 


\section{Metodologija}

Metode

Pri raziskovanju smo uporabili deskriptivno in kavzalno-neeksperimentalno metodo empiričnega pedagoškega raziskovanja, pri čemer smo uporabili kvantitativni pristop, ki je temeljil na statistični obdelavi numeričnih podatkov, pridobljenih s tehniko zbiranja podatkov z vprašalnikom.

Vrorec

Uporabili smo priložnosti neslučajnostni vzorec, v katerega smo vključili udeležence predstavitev učnih gradiv v organizaciji založbe DZS, ki so potekale v marcu $2019 \mathrm{v}$ Ljubljani, Mariboru, Celju, Novem mestu in Novi Gorici. Na tem mestu velja opozoriti, da je zaradi neslučajnostnega vzorca potrebna določena previdnost pri oblikovanja sklepov in posploševanju.

\section{Zbiranje podatkov}

Podatke smo zbirali z natisnjenim vprašalnikom, ki so ga izpolnili udeleženci omenjenih predstavitev. Skupaj smo prejeli 114 izpolnjenih vprašalnikov, od katerih štirje niso ustrezali dvema selekcijskima pogojema za uvrstitev v vzorec, in sicer: vsaj eno leto poučevanja $\mathrm{v}$ prvem vzgojno-izobraževalnem obdobju, trenutno opravljanje dela razrednika (delo $\mathrm{v}$ podaljšanem bivanja ali pomočnika učitelja ne ustreza pogoju) v prvem vzgojno-izobraževalnem obdobju. Zaradi anonimnosti anketiranja ne vemo, s koliko različnih šol prihajajo respondenti, upravičeno pa domnevamo, da vsaj s 50 šol, saj se je omenjenih predstavitev udeležilo natanko 200 učiteljev z 89 različnih šol.

\section{Obdelava podatkov}

Podatke iz anketnih vprašalnikov smo s pomočjo šifranta prenesli v elektronske preglednice in jih obdelali s programom SPSS. Najprej smo izvedli faktorsko analizo z metodo glavnih komponent, s katero smo preverjali veljavnost in zanesljivost instrumenta. Rezultati omenjene analize potrjujejo, da uporabljeni vprašalnik ustreza kriteriju konstruktne veljavnosti, saj prvi faktor pojasni $21,13 \%$ variance. 
Zanesljivost smo preverili $\mathrm{s}$ postopkom faktorizacije $(\mathrm{rtt}=0,852)$ ter $\mathrm{s}$ Cronbachovim $\alpha$-testom $(\alpha=0,904)$, ki sta pokazala, da gre za zanesljiv instrument. Zaradi velikega števila pomensko sorodnih spremenljivk smo se odločili, da s faktorsko analizo določimo skupne faktorje za nadaljnjo analizo podatkov. Preverjanje upravičenosti faktorske analize s testom KMO (Kaiser-Mayer-Olkinova mera) Bartlettovim $\chi^{2}$-preizkusom ( $\mathrm{f}=0,542, \chi^{2}=3625,092, \mathrm{p}=0,000$ ) potrjuje, $\mathrm{da}$ je faktorska analiza upravičena. $S$ faktorsko analizo $z$ rotacijo promax smo iz nabora 43 spremenljivk oblikovali 9 faktorjev oziroma dimenzij, za katere smo ocenili, da so smiselne za našo raziskavo (vse imajo lastno vrednost, višjo od 1). Seznam dimenzij in pripadajočih spremenljivk je prikazan v preglednici 1. Dva faktorja, katerih lastna vrednost je sicer presegala 1, smo zavrgli, ker sta združevala raznorodne spremenljivke in jima nismo mogli pripisati smiselnega konstrukta oziroma dimenzije.

Preglednica 1: Dimenzije, dobljene s faktorsko analizo in spremenljivke, ki tvorijo dimenzije.

\begin{tabular}{|c|c|c|}
\hline Dimenzije & \multicolumn{2}{|r|}{ Vrednost nasičevanja in opis spremenljivk, ki sestavljajo dimenzijo: } \\
\hline $\begin{array}{l}\text { Ocenjevanje, ki ne temelji } \\
\text { na vrednotenju odgovorov: }\end{array}$ & $\begin{array}{l}0,812 \\
0,766 \\
0,762 \\
0,649 \\
0,613\end{array}$ & $\begin{array}{l}\text { Vrednotenje izvedbe projektne naloge } \\
\text { Vrednotenje fizičnega izdelka } \\
\text { Vrednotenje praktične dejavnosti } \\
\text { Vrednotenje javne predstavitve } \\
\text { Vrednotenje vsebine portfolia }\end{array}$ \\
\hline $\begin{array}{l}\text { Povezovanje in interpretacija } \\
\text { podatkov (sklepanje, } \\
\text { povezovanje, vrednotenje, } \\
\text { argumentiranje): }\end{array}$ & $\begin{array}{l}0,823 \\
0,783 \\
0,760 \\
0,740 \\
0,647 \\
0,626 \\
0,503\end{array}$ & $\begin{array}{l}\text { Argumentiranje } \\
\text { Sklepanje (npr. ... zato, ker ...) } \\
\text { Povezovanje (npr. čim bolj ..., tem ...) } \\
\text { Vrednotenje informacij } \\
\text { Branje iz učbenikov ali drugih virov } \\
\text { Samostojno iskanje podatkov } \\
\text { Opisovanje (pojavov, naprav ...) }\end{array}$ \\
\hline $\begin{array}{l}\text { Lastna ocena motiviranosti } \\
\text { učitelja: }\end{array}$ & $\begin{array}{l}0,830 \\
0,826 \\
0,792 \\
0,765 \\
0,707 \\
0,663\end{array}$ & $\begin{array}{l}\text { Učiteljevo navdušenje nad poklicem } \\
\text { Učitelja delo navdihuje } \\
\text { Učitelj v svojem delu najde veliko smisla } \\
\text { Zadovoljstvo učitelja s svojim poklicem } \\
\text { Učitelj je ponosen na svoje delo } \\
\text { Učitelj želi svoj poklic še dolgo opravljati }\end{array}$ \\
\hline Biološke učne teme: & $\begin{array}{l}0,850 \\
0,792 \\
0,747 \\
0,599 \\
0,591\end{array}$ & $\begin{array}{l}\text { Živa bitja } \\
\text { Življenjska okolja } \\
\text { Ždrav način življenja } \\
\text { Človeško telo } \\
\text { Okoljska vzgoja }\end{array}$ \\
\hline
\end{tabular}




\begin{tabular}{lll}
\hline & 0,757 & Učenci samostojno načrtujejo poskuse (ali raziskave) \\
& 0,748 & Učenci predstavljajo rezultate poskusov (ali raziskav) \\
Izvajanje preprostih raziskav: & 0,614 & Učenci izvajajo poskuse (ali raziskave) po navodilih \\
& 0,610 & Učenci berejo iz učbenikov ali drugih virov \\
& 0,589 & Učenci izvajajo raziskave (npr. anketiranje) \\
\hline Urejanje in analiza podatkov & 0,895 & Urejanje (po določenih kriterijih) \\
(primerjanje, urejanje, & 0,885 & Razvrščanje (po določenih kriterijih) \\
razvrščanje): & 0,819 & Primerjanje (po določenih kriterijih) \\
\hline & 0,873 & Sile in gibanje \\
Fizikalne, kemijske & 0,784 & Zvok in svetloba \\
in tehnične učne teme: & 0,734 & Lastnosti snovi \\
& 0,532 & Prostor (geografski pojmi) \\
\hline \multirow{2}{*}{$\begin{array}{ll}\text { Delo z IKT } \\
\text { in elektronskimi vsebinami: }\end{array}$} & 0,793 & Učenci si ogledujejo interaktivne vsebine \\
& 0,761 & Učenci rešujejo interaktivne naloge \\
& 0,738 & Uporaba IKT \\
\hline \multirow{2}{*}{ Sociološke in psihološke teme: } & 0,715 & Skupnosti (šola, družina ...) \\
& 0,588 & Promet (pravila, varnost ...) \\
\hline
\end{tabular}

Za potrebe analize podatkov smo oblikovali tudi referenčne dimenzije (preglednica 2).

Preglednica 2: Referenčne dimenzije in spremenljivke, ki tvorijo dimenzije.

\begin{tabular}{ll}
\hline Dimenzije & Spremenljivke, ki sestavljajo dimenzijo: \\
\hline $\begin{array}{l}\text { Ocenjevanje znanja, ki temelji } \\
\text { na vrednotenju odgovorov: }\end{array}$ & $\begin{array}{l}\text { Vrednotenje ustnih odgovorov } \\
\text { Vrednotenje pisnega izdelka }\end{array}$ \\
\hline & Poslušajo učiteljevo razlago nove snovi \\
& Sprašujejo med razlago nove snovi \\
& Opazujejo učitelja pri izvajanju poskusa \\
& Rešujejo naloge v delovnem zvezku (ali na delovnih listih) \\
& Razpravljajo o obravnavani snovi \\
Druge aktivnosti & Opazujejo in opisujejo naravne pojave (npr. vreme) \\
in spoznavni procesi: & Usmerjeno opazovanje \\
& Merjenje in zapis meritev \\
& Grafično prikazovanje podatkov \\
& Interpretiranje grafičnih prikazov \\
\hline & Čas (dan, teden, leto ...) \\
Druge učne teme: & Obeč in danes \\
& Vremenava gradiv \\
\hline
\end{tabular}


Za analizo posameznih spremenljivk in dimenzij smo uporabili osnovno deskriptivno statistiko: aritmetično sredino $(\overline{\mathrm{X}})$ in standardni odklon (S). Razlike spremenljivke oziroma dimenzije glede na izbrani kriterij smo ugotavljali z neparametričnim Kruskal-Wallisovim H-preizkusom, ker niso bili izpolnjeni pogoji za parametrične preizkuse. S parametričnim t-preizkusom za odvisne vzorce smo preverjali razlike med dimenzijami.

\section{Rezultati in interpretacija}

\section{Profil respondentov}

V raziskavi je sodelovalo 114 respondentov, štirje so bili izločeni kot neustrezni. Od 110 respondentov, ki ustrezajo selekcijskim pogojem in so njihovi odgovori zajeti v analizi, je 50 (45,9\%) učiteljic 1. razreda, 25 (22,9\%) učiteljic 2. razreda, $21(19,3 \%)$ učiteljic 3. razreda in $13(11,9 \%)$ učiteljic kombiniranih oddelkov, ena učiteljica ni podala odgovora. Učitelja ni nobenega.

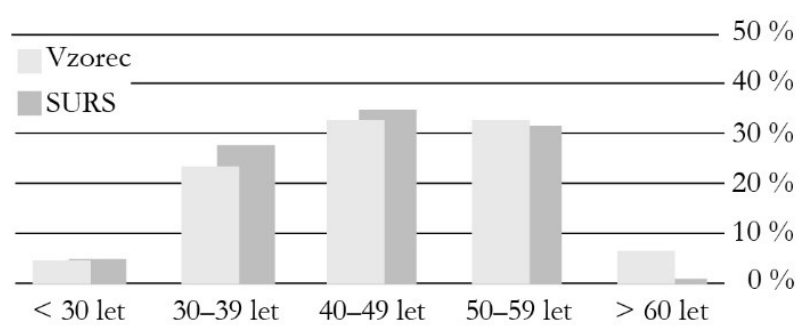

\begin{tabular}{lcc}
\hline Starost & $\mathrm{f}$ & \multicolumn{1}{c}{$\mathrm{f} \%$} \\
\hline Manj kot 30 let & 5 & 4,7 \\
\hline 30-39 let & 2 & 23,4 \\
\hline $40-49$ let & 3 & 32,7 \\
\hline 50-59 let & 3 & 32,7 \\
\hline 60 let in več & 7 & 6,5 \\
\hline Skupaj & 1 & 100,0 \\
\hline
\end{tabular}

Slika 3: Prikaz strukture učiteljic glede na njihovo starost (natančnejši podatki so v preglednici) našega vzorca $\mathrm{v}$ primerjavi z uradnimi podatki o starostni strukturi učiteljic prvega in drugega vzgojnoizobraževalnega obdobja v letu 2014 (SURS).

Učiteljice, zajete $\mathrm{v}$ raziskavi, so bile v povprečju stare 45 let in imele 21 let delovne dobe. Dobljena starostna struktura (slika 3) se dobro ujema z uradnim podatkom o starostni strukturi učiteljic 1. in 2. vzgojno-izobraževalnega obdobja v letu 2014 (SISTAT, 2018). 


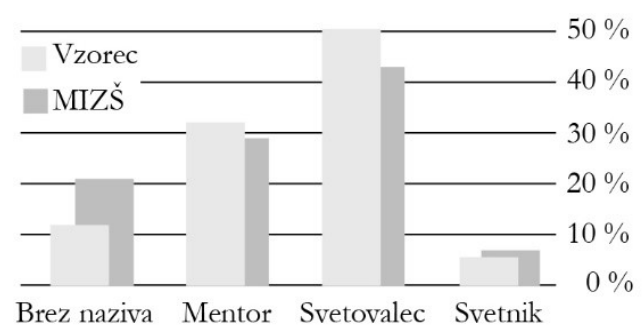

\begin{tabular}{lcc}
\hline Strokovni naziv & $\mathrm{f}$ & $\mathrm{f} \%$ \\
\hline Brez naziva & 1 & 11,9 \\
\hline Mentor & 3 & 32,1 \\
\hline Svetovalec & 5 & 50,5 \\
\hline Svetnik & 6 & 5,5 \\
\hline Skupaj & 1 & 100,0 \\
\hline
\end{tabular}

Slika 4. Prikaz strukture učiteljic glede na strokovni naziv (natančnejši podatki so v preglednici) našega vzorca $\mathrm{v}$ primerjavi $\mathrm{z}$ uradnimi podatki o strukturi strokovnih delavcev $\mathrm{v}$ osnovni šoli glede na strokovni naziv (MIZŠ).

Največ učiteljic, zajetih $\mathrm{v}$ raziskavi, ima naziv svetovalec (50,5\%). Ugotovljena struktura se z uradnimi podatki, pridobljenimi z Ministrstva za izobraževanje, znanost in šport razhaja predvsem pri učiteljicah brez naziva in učiteljicah z nazivom svetovalec (slika 4).

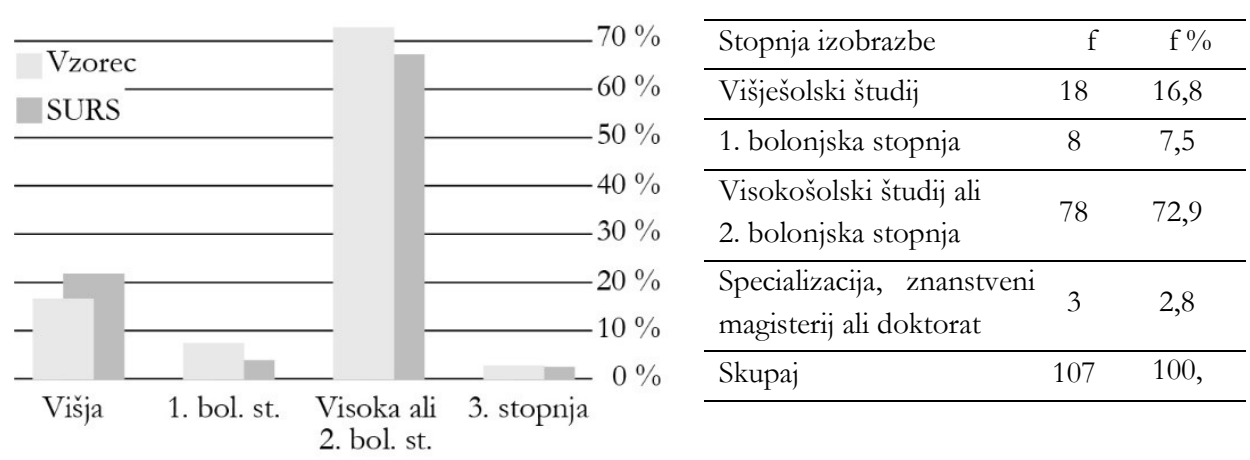

Slika 5. Prikaz strukture učiteljic glede na dokončano stopnjo izobrazbe (natančnejši podatki so v preglednici) našega vzorca $\mathrm{v}$ primerjavi z uradnimi podatki o izobrazbeni strukturi učiteljic 1 . in 2 . vzgojno-izobraževalnega obdobja v letu 2014 (SURS).

Največ učiteljic je kot najvišjo doseženo stopnjo izobrazbe navedlo zaključen 4-letni univerzitetni študij oziroma izobraževanje 2. bolonjske stopnje (72,9 \%). Ugotovljena izobrazbena struktura (slika 5) se dokaj dobro ujema z uradnim podatkom o izobrazbeni strukturi učiteljic 1. in 2. vzgojno-izobraževalnega obdobja v letu 2014 (SI-STAT, 2018). 
Kot vidimo na sliki 6, se približno četrtina učiteljic $(25,7 \%) \mathrm{v}$ zadnjih dveh letih v povezavi z učnim predmetom spoznavanje okolja po lastnih navedbah ni dodatno usposabljala, približno polovica (49,5\%) je opravila do 8 ur dodatnega usposabljanja. Če v izračunu povprečnega števila ur dodatnega usposabljanja upoštevamo zgornje meje intervalov, ugotovimo, da so se učiteljice $\mathrm{v}$ zadnjih dveh leti $\mathrm{v}$ povezavi $\mathrm{z}$ učnim predmetom spoznavanje okolja $\mathrm{v}$ povprečju dodatno usposabljale približno 8 ur.

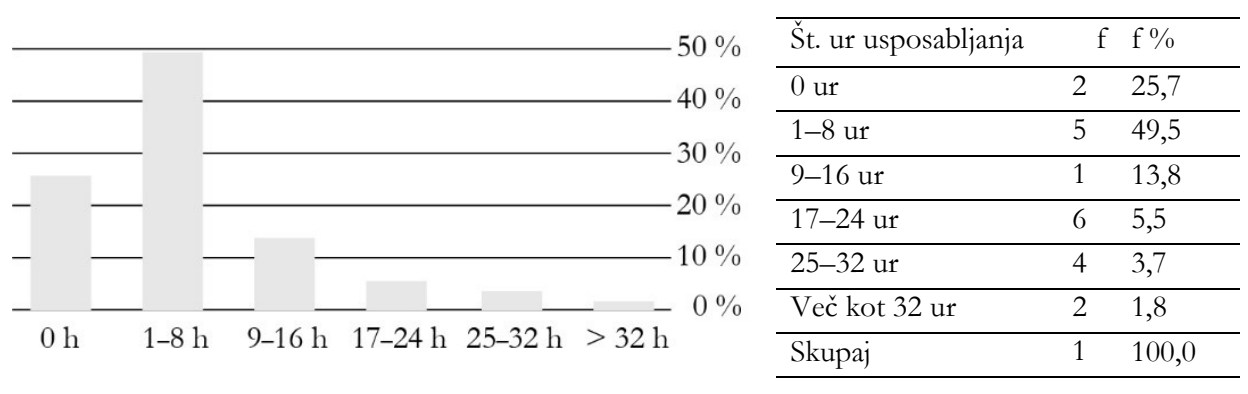

Slika 6. Prikaz strukture učiteljic glede na opravljene ure strokovnega usposabljanja v povezavi s predmetom spoznavanje okolja v zadnjih dveh letih (natančnejši podatki so v preglednici).

Na podlagi primerjav različnih struktur vzorca s pripadajočimi strukturami celotne populacije lahko sklepamo, da vzorec po osnovnih parametrih dobro odslikava celotno množico. Vzorec je po našem prepričanju tudi geografsko dovolj raznolik. Pri posploševanju rezultatov na celotno populacijo moramo biti kljub temu previdni, saj naš vzorec vendarle ni slučajnosten.

\section{Lastna ocena motiviranosti za delo}

Zanimalo nas je, ali obstajajo razlike v lastni oceni motiviranosti učiteljic glede na to, koliko let že poučujejo in glede na razred, v katerem poučujejo. 
Preglednica 3. Rezultat Kruskal-Wallisovega preizkusa za preverjanje razlik v lastne oceni motiviranosti glede na leta poučevanja učiteljic $\mathrm{v}$ našem vzorcu $(\mathrm{N}=109)$.

\begin{tabular}{|c|c|c|c|c|}
\hline \multirow[b]{2}{*}{ Leta poučevanja } & \multirow[b]{2}{*}{$\mathrm{n}$} & \multirow[b]{2}{*}{$\overline{\mathrm{R}}$} & \multicolumn{2}{|c|}{$\begin{array}{c}\text { Kruskal-Wallisov } \\
\text { H-test }\end{array}$} \\
\hline & & & $\mathrm{H}$ & $\mathrm{P}$ \\
\hline 10 let in manj & 19 & 57,74 & \multirow{4}{*}{0,639} & \multirow{4}{*}{0,687} \\
\hline $11-20$ let & 38 & 56,68 & & \\
\hline 21-30 let & 22 & 50,98 & & \\
\hline 31 let in več & 30 & 54,08 & & \\
\hline
\end{tabular}

Rezultat Kruskal-Wallisovega preizkusa $(\mathrm{H}=0,639, \mathrm{P}=0,687)$ pokaže, da med učiteljicami z različnim številom let poučevanja ne obstajajo statistično pomembne razlike v lastni oceni motiviranosti.

Preglednica 4. Rezultat Rezultat Kruskal-Wallisovega preizkusa za preverjanje razlik v lastni oceni motiviranosti glede na razred, $\mathrm{v}$ katerem poučujejo učiteljice $\mathrm{v}$ našem vzorcu $(\mathrm{N}=108)$.

\begin{tabular}{lcccc}
\hline & \multicolumn{3}{c}{ Kruskal-Wallisov } \\
\hline Razred & $\mathrm{n}$ & $\overline{\mathrm{R}}$ & $\mathrm{H}$ & $\mathrm{P}$ \\
\hline 1. razred & 49 & 49,74 & & \\
\cline { 1 - 2 } 2. razred & 25 & 52,68 & & \\
\cline { 1 - 3 } 3. razred & 21 & 65,990 & 0,263 \\
\cline { 1 - 2 } Kombinirani oddelki & 13 & 58,35 & & \\
\hline
\end{tabular}

Rezultat Kruskal-Wallisovega preizkusa $(\mathrm{H}=3,990, \mathrm{P}=0$,263) pokaže, da tudi med učiteljicami, ki poučujejo $\mathrm{v}$ različnih razredih, ne obstajajo statistično pomembne razlike v lastni oceni motiviranosti. 


\section{Lastna ocena kompetentnosti za poučevanje posameznih ünih predmetov}

Pri vprašanju, kateri učni predmet najbolj oziroma najmanj rade poučujejo, in pri vprašanju, za poučevanje katerega učnega predmet se počutijo najbolj oziroma najmanj kompetentne, je več kot četrtina učiteljic podala neveljavne odgovore (kot kaže, se niso mogle odločiti le za en odgovor).

Preglednica 5. Število in strukturni odstotek (v oklepaju) učiteljic glede na to, kateri predmet najraje/najmanj rade poučujejo oziroma glede na oceno lastne kompetentnosti za poučevanje posameznega predmeta.

\begin{tabular}{lccccccc}
\hline Trditev & MAT & SLJ & SPO & LUM & GUM & ŠPO & Skupaj \\
\hline $\begin{array}{l}\text { Najraje } \\
\text { poučujem }\end{array}$ & $\begin{array}{c}37 \\
(53,6 \%)\end{array}$ & $\begin{array}{c}20 \\
(29,0 \%)\end{array}$ & $\begin{array}{c}7 \\
(10,1 \%)\end{array}$ & $\begin{array}{c}4 \\
(5,8 \%)\end{array}$ & $\begin{array}{c}1 \\
(1,5 \%)\end{array}$ & $\begin{array}{c}0 \\
(0,0 \%)\end{array}$ & $\begin{array}{c}69 \\
(100 \%)\end{array}$ \\
\hline $\begin{array}{l}\text { Najmanj rad(a) } \\
\text { poučujem }\end{array}$ & $\begin{array}{c}4 \\
(5,1 \%)\end{array}$ & $\begin{array}{c}1 \\
(1,3 \%)\end{array}$ & $\begin{array}{c}7 \\
(8,9 \%)\end{array}$ & $\begin{array}{c}9 \\
(11,4 \%)\end{array}$ & $\begin{array}{c}44 \\
(55,7 \%)\end{array}$ & $\begin{array}{c}14 \\
(17,7 \%)\end{array}$ & \begin{tabular}{c}
$700 \%)$ \\
\hline Najbolj sem
\end{tabular} \\
kompetenten/-na za & $(52,8 \%)$ & $\begin{array}{c}23 \\
(31,9 \%)\end{array}$ & $\begin{array}{c}5 \\
(6,9 \%)\end{array}$ & $\begin{array}{c}2 \\
(2,8 \%)\end{array}$ & $\begin{array}{c}(5,6 \%) \\
(0,0 \%)\end{array}$ & $(100 \%)$ \\
\hline $\begin{array}{l}\text { Najmanj sem } \\
\text { Kompetenten/-na za }\end{array}$ & 3 & 0 & 6 & 17 & 40 & 13 & 79 \\
\hline
\end{tabular}

Zato nismo opravili podrobnejše statistične analize omenjenih dveh vprašanj, kljub temu smo ugotovili, da učni predmet spoznavanje okolja, ki nas posebej zanima, pri nobenem od naštetih vprašanj ne izstopa (preglednica 5). Za omenjeni učni predmet lahko upravičeno domnevamo, da ga učiteljice rade poučujejo oziroma se za njegovo poučevanje počutijo kompetentne, saj je po "priljubljenosti« oziroma »kompetentnosti« takoj za matematiko in slovenščino ter ga le manjši del učiteljic (8,9\% oz. 7,6\%) postavlja na zadnje mesto.

\section{Izvajanje pouka naravoslovja izven matične učilnice}

Zanimalo nas je (Preglednica 6), kako pogosto učiteljice izvajajo pouk naravoslovja izven matične učilnice. Ugotovili smo, da večina učiteljic ( $91,7 \%$ ) vsaj trikrat na leto izvaja pouk spoznavanja okolja $\mathrm{v}$ naravi (od tega dobri dve tretjini več kot petkrat letno), da slabi dve tretjini učiteljic $(63,3 \%)$ vsaj trikrat na leto $z$ učenci obiščeta različne vzgojno-izobraževalne ustanove, le 38,9 \% učiteljic pa več kot trikrat letno uporabi računalniško učilnico. (Podrobnejši podatki so v preglednici 6.) Če smo 
lahko s pogostostjo izvajanja pouka v naravi zmerno zadovoljni, pa tega ne moremo trditi za izvajanje pouka $\mathrm{v}$ računalniški učilnici ter različnih kulturnih in izobraževalnih ustanovah.

Preglednica 6. Število in strukturni odstotek učiteljic glede na to, kako pogosto izvajajo pouk spoznavanja okolja $\mathrm{v}$ računalniški učilnici, $\mathrm{v}$ naravi (izven območja šole) ter $\mathrm{v}$ različnih kulturnih in izobraževalnih ustanovah $(\mathrm{N}=108,109,109)$.

\begin{tabular}{lcccccc}
\hline & $\mathrm{V}$ & računalniški & V naravi & & $\mathrm{V}$ & kulturnih \\
\hline Pogostost & $\mathrm{f}$ & $\mathrm{f} \%$ & $\mathrm{f}$ & $\mathrm{f} \%$ & $\mathrm{f}$ & $\mathrm{f} \%$ \\
\hline Več kot 5-krat letno & 15 & 13,9 & 70 & 64,2 & 20 & 18,3 \\
\hline 3- do 5-krat letno & 27 & 25,0 & 30 & 27,5 & 49 & 45,0 \\
\hline 1- do 2-krat letno & 39 & 36,1 & 7 & 6,4 & 34 & 31,2 \\
\hline Nikoli & 27 & 25,0 & 2 & 1,8 & 6 & 5,5 \\
\hline
\end{tabular}

$\mathrm{Ob}$ tem ne gre pozabiti, da je $\mathrm{v}$ predmetniku osnovne šole $\mathrm{v}$ vsakem razredu predvidenih 15 dni dejavnosti, pri katerih naj bi bil pouk zastavljen drugače kot običajno, tudi v smislu mesta izvajanja pouka.

\section{Oblike ocenjevanja}

Zanimalo nas je, ali obstajajo razlike $\mathrm{v}$ pogostosti uporabe različnih oblik ocenjevanja znanja glede na to, koliko let že poučujejo, in glede na razred, v katerem poučujejo.

Preglednica 7: Rezultat Kruskal-Wallisovega preizkusa za preverjanje razlik v pogostosti uporabe oblik ocenjevanja znanja pri predmetu spoznavanje okolja, ki ne temeljijo na vrednotenju odgovorov glede na leta poučevanja učiteljic $(\mathrm{N}=109)$.

\begin{tabular}{|c|c|c|c|c|}
\hline & & & \multicolumn{2}{|c|}{ Kruskal-Wallisov } \\
\hline Leta poučevanja & $\mathrm{n}$ & $\overline{\mathrm{R}}$ & $\mathrm{H}$ & $\mathrm{P}$ \\
\hline 10 let in manj & 19 & 57,58 & \multirow{4}{*}{0,398} & \multirow{4}{*}{0,941} \\
\hline 11-20 let & 38 & 53,78 & & \\
\hline 21-30 let & 22 & 57,30 & & \\
\hline 31 let in več & 30 & 53,23 & & \\
\hline
\end{tabular}


Rezultat Kruskal-Wallisovega preizkusa $(\mathrm{H}=0,398, \mathrm{P}=0,941)$ pokaže, da med učiteljicami z različnim številom let poučevanja ne obstajajo statistično pomembne razlike $\mathrm{v}$ pogostosti uporabe oblik ocenjevanja znanja, ki ne temeljijo na vrednotenju odgovorov.

Preglednica 8. Rezultat Kruskal-Wallisovega preizkusa za preverjanje razlik v pogostosti uporabe oblik ocenjevanja, ki ne temeljijo na vrednotenju odgovorov glede na razred, v katerem poučujejo učiteljice v našem vzorcu $(\mathrm{N}=108)$.

\begin{tabular}{lcccc}
\hline & \multicolumn{3}{c}{ Kruskal-Wallisov } \\
\hline Razred & $\mathrm{n}$ & $\overline{\mathrm{R}}$ & $\mathrm{H}$ & $\mathrm{P}$ \\
\hline 1. razred & 49 & 55,70 & & \\
\cline { 1 - 2 } 2. razred & 25 & 54,86 & & \\
\cline { 1 - 3 } 3. razred & 21 & 59,046 & & 0,449 \\
\cline { 1 - 3 } Kombinirani oddelki & 13 & 41,92 & & \\
\hline
\end{tabular}

Rezultat Kruskal-Wallisovega preizkusa $(\mathrm{H}=2,646, \mathrm{P}=0,449)$ pokaže, da tudi med učiteljicami, ki poučujejo $\mathrm{v}$ različnih razredih, ne obstajajo statistično pomembne razlike $v$ pogostosti uporabe oblik ocenjevanja znanja, ki ne temeljijo na vrednotenju odgovorov.

Preglednica 9. Rezultat t-preizkusa za odvisne vzorce za pogostost uporabe oblik ocenjevanja, ki ne temeljijo na vrednotenju odgovorov in oblik ocenjevanja, temelječih na vrednotenju odgovorov.

\begin{tabular}{|c|c|c|c|c|c|c|c|}
\hline \multirow{2}{*}{ Dimenzija } & \multirow{2}{*}{$\overline{\mathrm{X}}$} & \multirow{2}{*}{ S } & \multicolumn{2}{|c|}{ Korelacija } & \multicolumn{3}{|c|}{ T-preizkus } \\
\hline & & & $\mathrm{R}$ & $\mathrm{P}$ & $\mathrm{t}$ & $\mathrm{g}$ & $2 \mathrm{P}$ \\
\hline Oblike ocenjevanja & 2,80 & 0,67 & \multirow{2}{*}{0,146} & \multirow{2}{*}{0,130} & \multirow{2}{*}{15,068} & \multirow{2}{*}{108} & \multirow{2}{*}{0,000} \\
\hline Oblike ocenjevanja & 1,63 & 0,56 & & & & & \\
\hline
\end{tabular}

$$
* \mathrm{~N}=109
$$

Rezultat t-preizkusa za odvisne vzorce za preverjanje razlik v pogostosti uporabe obeh oblik ocenjevanja znanja pokaže, da sta pogostosti njune uporabe nizko pozitivno in statistično povezani $(\mathrm{R}=0,146, \mathrm{P}=0,130)$. T-preizkus pokaže $(\mathrm{t}=$ $15,068, \mathrm{~g}=108,2 \mathrm{P}=0,000)$, da med pogostostjo uporabe obeh oblik ocenjevanja obstajajo statistično pomembne razlike. Učiteljice v povprečju pogosteje uporabljajo 
oblike ocenjevanja, ki temelijo na vrednotenju odgovorov $(\overline{\mathrm{X}}=1,63)$, kot oblike ocenjevanja, ki ne temeljijo na vrednotenju odgovorov $(\overline{\mathrm{X}}=2,80)$.

Če zagovarjamo tezo, da raznolikost in uravnoteženost oblik ocenjevanja znanja pripomore $\mathrm{k}$ boljšemu naravoslovnemu znanju oziroma kapitalu učencev, lahko iz dobljenih podatkov z gotovostjo sklepamo, da na področju ocenjevanja znanja obstajajo možnosti za izboljšave.

\section{Izvajanje različnih aktivnosti z.vključenimi določenimi naravoslovnimi postopki}

Zanimalo nas je, ali obstajajo razlike $\mathrm{v}$ pogostosti izvajanja določenih aktivnosti (izbor temelji na dimenzijah, dobljenih s faktorsko analizo) glede na to, koliko let učiteljice že poučujejo in glede na razred, $v$ katerem poučujejo. Rezultati KruskalWallisovih preizkusov $\left(\mathrm{H}_{1}=5,860, \mathrm{P}_{1}=0,119 ; \mathrm{H}_{2}=3,730, \mathrm{P}_{2}=0,292 ; \mathrm{H}_{3}=5,608\right.$, $\mathrm{P}_{3}=0,132 ; \mathrm{H}_{4}=3,781, \mathrm{P}_{4}=0,286$ ) (Preglednica 10) za preverjanje razlik glede pogostosti izvajanja izbranih aktivnosti pokažejo, da med učiteljicami z različnim številom let poučevanja ne obstajajo statistično pomembne razlike $\mathrm{v}$ pogostosti izvajanja aktivnosti, ki vključujejo izbrane postopke. (Podrobnejši prikaz rezultatov je v preglednici 10.)

Preglednica 10. Rezultati Kruskal-Wallisovih preizkusov za preverjanje razlik v pogostosti aktivnosti, ki vključujejo izbrane postopke, glede na leta poučevanja učiteljic v našem vzorcu $(N=110)$.

\begin{tabular}{|c|c|c|c|c|c|c|c|c|}
\hline \multirow[b]{2}{*}{ Leta poučevanja } & \multicolumn{2}{|c|}{ Povezovanje } & \multicolumn{2}{|c|}{ Izvajanje } & \multicolumn{2}{|c|}{ Urejanje } & \multicolumn{2}{|c|}{ Delo z IK'T in } \\
\hline & $\mathrm{n}$ & $\overline{\mathrm{R}}$ & $\mathrm{n}$ & $\overline{\mathrm{R}}$ & $\mathrm{n}$ & $\overline{\mathrm{R}}$ & $\mathrm{n}$ & $\overline{\mathrm{R}}$ \\
\hline 10 let in manj & 19 & 55,74 & 19 & 61,21 & 19 & 47,08 & 19 & 54,21 \\
\hline $11-20$ let & 39 & 64,73 & 39 & 60,85 & 39 & 61,67 & 39 & 63,13 \\
\hline 21-30 let & 22 & 50,20 & 22 & 50,50 & 22 & 44,50 & 22 & 50,45 \\
\hline 31 let in več & 30 & 47,40 & 30 & 48,60 & 30 & 52,92 & 30 & 50,10 \\
\hline \multirow{2}{*}{$\begin{array}{l}\text { Kruskal-Wallisov } \\
\text { H-test }\end{array}$} & \multicolumn{2}{|c|}{$\mathrm{H}_{1}=5,860$} & \multicolumn{2}{|c|}{$\mathrm{H}_{2}=3,730$} & \multicolumn{2}{|c|}{$\mathrm{H}_{3}=5,608$} & \multicolumn{2}{|c|}{$\mathrm{H}_{4}=3,781$} \\
\hline & \multicolumn{2}{|c|}{$P_{1}=0,119$} & \multicolumn{2}{|c|}{$\mathrm{P}_{2}=0,292$} & \multicolumn{2}{|c|}{$\mathrm{P}_{3}=0,132$} & \multicolumn{2}{|c|}{$P_{4}=0,286$} \\
\hline
\end{tabular}

Kljub temu lahko v preglednici 10 opazimo, da učiteljice, ki poučujejo med 11 in 20 leti, najpogosteje izvajajo aktivnosti, povezane z izbranimi postopki. 
Preglednica 11. Rezultati Kruskal-Wallisovih preizkusov za preverjanje razlik v pogostosti izvajanja aktivnosti, ki vključujejo izbrane postopke, glede na razred, $\mathrm{v}$ katerem poučujejo učiteljice $\mathrm{v}$ našem vzorcu $(\mathrm{N}=109)$.

\begin{tabular}{|c|c|c|c|c|c|c|c|c|}
\hline \multirow[b]{2}{*}{ Razred } & \multicolumn{2}{|c|}{ Povezovanje } & \multicolumn{2}{|c|}{ Izvajanje } & \multicolumn{2}{|c|}{ Urejanje } & \multicolumn{2}{|c|}{ Delo z IKT in } \\
\hline & $\mathrm{n}$ & $\overline{\mathrm{R}}$ & $\mathrm{n}$ & $\overline{\mathrm{R}}$ & $\mathrm{n}$ & $\overline{\mathrm{R}}$ & $\mathrm{n}$ & $\overline{\mathrm{R}}$ \\
\hline 1. razred & 50 & 65,18 & 50 & 60,21 & 50 & 48,46 & 50 & 57,07 \\
\hline 2. razred & 25 & 42,04 & 25 & 50,74 & 25 & 57,98 & 25 & 53,36 \\
\hline 3. razred & 21 & 53,81 & 21 & 57,60 & 21 & 64,61 & 21 & 51,69 \\
\hline Kombinirani & 13 & 42,69 & 13 & 38,96 & 13 & 43,00 & 13 & 55,54 \\
\hline \multirow{2}{*}{$\begin{array}{l}\text { Kruskal-Wallisov } \\
\text { H-test }\end{array}$} & \multicolumn{2}{|c|}{$\mathrm{H}_{1}=11,495$} & \multicolumn{2}{|c|}{$\mathrm{H}_{2}=5,419$} & \multicolumn{2}{|c|}{$\mathrm{H}_{3}=6,309$} & \multicolumn{2}{|c|}{$\mathrm{H}_{4}=0,531$} \\
\hline & \multicolumn{2}{|c|}{$P_{1}=0,009$} & \multicolumn{2}{|c|}{$P_{2}=0,114$} & \multicolumn{2}{|c|}{$P_{3}=0,098$} & \multicolumn{2}{|c|}{$P_{4}=0,912$} \\
\hline
\end{tabular}

Rezultati Kruskal-Wallisovih preizkusov $\left(\mathrm{H}_{1}=11,495, \mathrm{P}_{1}=0,009 ; \mathrm{H}_{2}=5,419, \mathrm{P}_{2}=\right.$ 0,$\left.114 ; \mathrm{H}_{3}=6,309, \mathrm{P}_{3}=0,098 ; \mathrm{H}_{4}=0,531, \mathrm{P}_{4}=0,912\right)$ za preverjanje razlik glede pogostosti izvajanja aktivnosti, ki vključujejo izbrane postopke, pokažejo, da med učiteljicami, ki poučujejo $\mathrm{v}$ različnih razredih obstajajo statistično pomembne razlike le pri pogostosti izvajanja aktivnosti, ki vključujejo povezovanje in interpretacijo podatkov. Iz preglednice 11 je razvidno, da učiteljice 2. razredov $(\overline{\mathrm{R}}=42,04)$ in kombiniranih oddelkov $(\overline{\mathrm{R}}=42,69)$ v povprečju najpogosteje izvajajo aktivnosti, ki vključujejo povezovanje in interpretacijo podatkov, učiteljice 1. razredov pa jih $\mathrm{v}$ povprečju izvajajo najredkeje $(\overline{\mathrm{R}}=65,81)$. Rezultat za 1 . razred je v skladu s pričakovanji, saj gre za zahtevnejše spoznavne procese, ki jih je pri višji starosti učencev lažje in smiselneje izvajati, ne moremo pa na ta način pojasniti dejstva, da je pogostost izvajanja omenjenih dejavnosti v 3 . razredu manjša kot v 2. razredu.

Zanimala nas je tudi primerjava pogostosti izvajanja izbranih aktivnosti s pogostostjo izvajanja drugih aktivnosti.

Rezultati t-preizkusov (Preglednica 12) za odvisne vzorce za preverjanje razlik pogostosti izvajanja posameznih izbranih aktivnosti s pogostostjo izvajanja drugih aktivnosti pokažejo, da gre $\mathrm{v}$ vseh primerih za pozitivno in šibko do zmerno statistično povezanost $\left(\mathrm{R}_{1}=0,464,2 \mathrm{P}_{1}=0,114 ; \mathrm{R}_{2}=0,394,2 \mathrm{P}_{2}=0,000 ; \mathrm{R}_{3}=0,390\right.$, $\left.2 \mathrm{P}_{3}=0,006 ; \mathrm{R}_{4}=0,420,2 \mathrm{P}_{4}=0,000\right)$. 
Preglednica 12. Rezultat t-preizkusa za odvisne vzorce za pogostost uporabe aktivnosti, ki vključujejo izbrane postopke in aktivnosti, ki jih ne vključujejo.

\begin{tabular}{|c|c|c|c|c|c|c|c|}
\hline \multirow{2}{*}{ Dimenzija } & \multirow{2}{*}{$\overline{\mathrm{X}}$} & \multirow{2}{*}{ S } & \multicolumn{2}{|c|}{ Korelacija } & \multirow[b]{2}{*}{$\mathrm{t}$} & \multicolumn{2}{|c|}{ T-preizkus } \\
\hline & & & $\mathrm{R}$ & $\mathrm{P}$ & & g & $2 \mathrm{P}$ \\
\hline Povezovanje in & 2,32 & 0,58 & \multirow{2}{*}{0,464} & \multirow{2}{*}{0,000} & \multirow{2}{*}{1,594} & \multirow{2}{*}{109} & \multirow{2}{*}{0,114} \\
\hline Druge aktivnosti & 2,24 & 0,35 & & & & & \\
\hline Izvajanje preprostih & 3,04 & 0,45 & \multirow{2}{*}{0,394} & \multirow{2}{*}{0,000} & \multirow{2}{*}{18,825} & \multirow{2}{*}{109} & \multirow{2}{*}{0,000} \\
\hline Druge aktivnosti & 2,24 & 0,35 & & & & & \\
\hline Urejanje in analiza & 2,40 & 0,58 & \multirow{2}{*}{0,390} & \multirow{2}{*}{0,000} & \multirow{2}{*}{2,789} & \multirow{2}{*}{105} & \multirow{2}{*}{0,006} \\
\hline Druge aktivnosti & 2,24 & 0,33 & & & & & \\
\hline Delo z IKT- in e- & 2,64 & 0,63 & \multirow{2}{*}{0,420} & \multirow{2}{*}{0,000} & \multirow{2}{*}{7,386} & \multirow{2}{*}{109} & \multirow{2}{*}{0,000} \\
\hline Druge aktivnosti & 2,24 & 0,35 & & & & & \\
\hline
\end{tabular}

T-preizkusi pokažejo, da z izjemo aktivnosti, ki vključujejo povezovanje in interpretacijo podatkov, med pogostostjo izvajanja izbranih aktivnosti in pogostostjo izvajanja drugih aktivnosti obstajajo statistično pomembne razlike. Iz preglednice 12 je razvidno, da učiteljice $\mathrm{v}$ povprečju manj pogosto kot druge aktivnosti $(\overline{\mathrm{X}}=2,24 \mathrm{oz} .2,25)$ izvajajo aktivnosti, ki vključujejo preproste raziskave $(\overline{\mathrm{X}}=3,04)$, urejenje in analizo podatkov $\overline{\mathrm{X}}=2,40)$ in uporabo IKT in elektronskih vsebin $(\overline{\mathrm{X}}=2,64)$.

\section{Pripravljenost za poučevanje posameznih tematskih sklopov}

Zanimalo nas je, ali obstajajo razlike $\mathrm{v}$ pripravljenosti učiteljic za poučevanje izbranih tematskih sklopov (izbor temelji na dimenzijah, dobljenih s faktorsko analizo) glede na to, koliko let učiteljice že poučujejo, in glede na razred, v katerem poučujejo.

Rezultati Kruskal-Wallisovih preizkusov $\left(\mathrm{H}_{1}=1,901, \mathrm{P}_{1}=0,407 ; \mathrm{H}_{2}=3,416, \mathrm{P}_{2}=\right.$ 0,$\left.332 ; \mathrm{H}_{3}=1,607, \mathrm{P}_{3}=0,658\right)$ za preverjanje razlik glede pripravljenosti učiteljic za izvajanje izbranih treh tematskih sklopov kažejo, med učiteljicami z različnim številom let poučevanja ne obstajajo statistično pomembne razlike $\mathrm{v}$ pripravljenosti za izvajanje izbranih treh tematskih sklopov. (Podrobnejši prikaz rezultatov je v preglednici 13.) 
Preglednica 13. Rezultati Kruskal-Wallisovih preizkusov za preverjanje razlik v pripravljenosti učiteljic za poučevanje izbranih tematskih sklopov glede na leta poučevanja učiteljic $\mathrm{v}$ našem vzorcu $(\mathrm{N}=109)$.

\begin{tabular}{lccccccc}
\hline & \multicolumn{2}{c}{$\begin{array}{c}\text { Biološke } \\
\text { teme }\end{array}$} & $\begin{array}{c}\text { Fizikalne, } \\
\text { kemijske in } \\
\text { tehniške teme }\end{array}$ & \multicolumn{2}{c}{$\begin{array}{c}\text { Sociološke } \\
\text { in psihološke } \\
\text { teme }\end{array}$} \\
\hline Leta poučevanja & $\mathrm{n}$ & $\overline{\mathrm{R}}$ & $\mathrm{n}$ & $\overline{\mathrm{R}}$ & $\mathrm{n}$ & $\overline{\mathrm{R}}$ \\
\hline 10 let in manj & 19 & 55,68 & 19 & 61,84 & 19 & 57,24 \\
\hline 11-20 let & 39 & 61,13 & 39 & 59,09 & 39 & 58,79 \\
\hline 21-30 let & 22 & 49,57 & 22 & 51,57 & 22 & 49,64 \\
\hline 31 let in več & 30 & 50,40 & 30 & 47,75 & 30 & 52,40 \\
\hline $\begin{array}{l}\text { Kruskal-Wallisov } \\
\text { H-test }\end{array}$ & $\mathrm{H}_{1}=1,901$ & $\mathrm{H}_{2}=3,416$ & & $\mathrm{H}_{3}=1,607$ \\
\hline
\end{tabular}

Preglednica 14. Rezultati Kruskal-Wallisovih preizkusov za preverjanje razlik v pripravljenosti učiteljic za poučevanje izbranih tematskih sklopov glede na razred, $v$ katerem poučujejo učiteljice $v$ našem vzorcu.

\begin{tabular}{lccccccc}
\hline & \multicolumn{2}{c}{$\begin{array}{c}\text { Biološke } \\
\text { teme }\end{array}$} & $\begin{array}{c}\text { Fizikalne, } \\
\text { kemijske in } \\
\text { tehniške teme }\end{array}$ & $\begin{array}{c}\text { Sociološke } \\
\text { in psihološke } \\
\text { teme }\end{array}$ \\
\hline Razred & $\mathrm{n}$ & $\overline{\mathrm{R}}$ & $\mathrm{n}$ & $\overline{\mathrm{R}}$ & $\mathrm{n}$ & $\overline{\mathrm{R}}$ \\
\hline 1. razred & 50 & 55,13 & 50 & 58,33 & 50 & 49,67 \\
\hline 2. razred & 25 & 50,32 & 25 & 48,24 & 25 & 52,76 \\
\hline 3. razred & 21 & 56,03 & 21 & 53,98 & 21 & 70,43 \\
\hline Kombinirani oddelki & 13 & 57,77 & 13 & 52,62 & 13 & 51,92 \\
\hline $\begin{array}{l}\text { Kruskal-Wallisov } \\
\text { H-test }\end{array}$ & $\mathrm{H} 1=0,694$ & $\mathrm{H} 2=1,825$ & $\mathrm{H} 3=7,150$ \\
\cline { 2 - 7 } & $\mathrm{P} 1=0,875$ & $\mathrm{P} 2=0,610$ & $\mathrm{P} 3=0,067$ \\
\hline
\end{tabular}

Rezultati Kruskal-Wallisovih preizkusov $\left(\mathrm{H}_{1}=0,694, \mathrm{P}_{1}=0,875 ; \mathrm{H}_{2}=1,825, \mathrm{P}_{2}=\right.$ 0,$\left.610 ; \mathrm{H}_{3}=7,150, \mathrm{P}_{3}=0,067\right)$ za preverjanje razlik glede pripravljenosti učiteljic za izvajanje izbranih tematskih sklopov kažejo, da med učiteljicami, ki poučujejo $\mathrm{v}$ različnih razredih ne obstajajo statistično pomembne razlike $\mathrm{v}$ pripravljenosti za 
izvajanje izbranih tematskih sklopov. (Podrobnejši prikaz rezultatov je $\mathrm{v}$ preglednici 14.)

Zanimala nas je tudi primerjava pripravljenosti učiteljic za izvajanje izbranih treh tematskih sklopov s pripravljenostjo učiteljic za izvajanje drugih tematskih sklopov.

Rezultati t-preizkusov za odvisne vzorce za preverjanje razlik pripravljenosti za izvajanje izbranih tematskih sklopov s pripravljenostjo za izvajanje drugih tematskih sklopov pokažejo, da gre $\mathrm{v}$ vseh treh primerih za pozitivno in zmerno statistično povezanost $\left(\mathrm{R}_{1}=0,478, \mathrm{R}_{2}=0,637, \mathrm{R}_{3}=0,460,2 \mathrm{P}_{1}=2 \mathrm{P}_{2}=2 \mathrm{P}_{3}=0,000\right)$ (Preglednica 15). T-preizkusi pokažejo, da med pripravljenostjo za izvajanje vseh treh izbranih tematskih sklopov in pripravljenostjo za izvajanje drugih tematskih sklopov obstajajo statistično pomembne razlike.

Preglednica 15. Rezultati t-preizkusov za odvisne vzorce za pripravljenost učiteljic za izvajanje izbranih vsebin in drugih vsebin.

\begin{tabular}{|c|c|c|c|c|c|c|c|c|}
\hline \multirow{2}{*}{ Dimenzija } & \multirow{2}{*}{$\overline{\mathrm{X}}$} & \multirow{2}{*}{$\mathrm{N}$} & \multirow{2}{*}{ S } & \multicolumn{2}{|c|}{ Korelacija } & \multicolumn{3}{|c|}{ T-preizkus } \\
\hline & & & & $\mathrm{R}$ & $\mathrm{P}$ & $\mathrm{t}$ & $\mathrm{g}$ & $2 \mathrm{P}$ \\
\hline Biološke teme & 1,40 & 109 & 0,47 & \multirow{2}{*}{0,478} & \multirow{2}{*}{0,000} & \multirow{2}{*}{$-4,654$} & \multirow{2}{*}{108} & \multirow{2}{*}{0,000} \\
\hline Druge teme & 1,61 & 109 & 0,46 & & & & & \\
\hline $\begin{array}{l}\text { Fizikalne, kemijske } \\
\text { in tehniške teme }\end{array}$ & 2,15 & 109 & 0,62 & \multirow[t]{2}{*}{0,637} & \multirow[t]{2}{*}{0,000} & \multirow[t]{2}{*}{11,743} & \multirow[t]{2}{*}{108} & \multirow[t]{2}{*}{0,000} \\
\hline Druge teme & 1,61 & 109 & 0,46 & & & & & \\
\hline $\begin{array}{l}\text { Sociološke in } \\
\text { psihološke teme }\end{array}$ & 2,41 & 109 & 0,46 & \multirow[t]{2}{*}{0,460} & \multirow[t]{2}{*}{0,000} & \multirow[t]{2}{*}{$-4,322$} & \multirow[t]{2}{*}{108} & \multirow[t]{2}{*}{0,000} \\
\hline Druge teme & 1,61 & 109 & 0,46 & & & & & \\
\hline
\end{tabular}

Kot je razvidno iz preglednice 15 , učiteljice $\mathrm{v}$ povprečju izražajo večjo pripravljenost za izvajanje bioloških vsebin $(\overline{\mathrm{X}}=1,40)$ kot za izvajanje drugih vsebin $(\overline{\mathrm{X}}=1,61)$, hkrati pa nižjo pripravljenost za izvajanje fizikalnih, kemijskih in tehniških vsebin $\overline{\mathrm{X}}$ $=2,15)$ ter socioloških in psiholoških vsebin $(\bar{X}=2,41)$ kot za izvajanje drugih vsebin. Rezultati za biološke ter fizikalne, kemijske in tehniške vsebin so pričakovani, 
saj veljajo za manj oziroma bolj zahtevne, rezultata za sociološke in psihološke teme pa si ne znamo zadovoljivo pojasniti.

\section{Sklep}

\section{Ugotovitue}

Primerjava osnovnih lastnosti vzorca s podatki za celotno populacijo kaže, da vzorec, kljub temu da ni slučajnosten, po omenjenih lastnostih zadovoljivo odslikava populacijo. Tudi instrument se je izkazal za ustreznega.

Ugotovili smo, da izkušenost učiteljic in razred, v katerem poučujejo, glede na uporabljene statistične metod ne vpliva na njihovo motivacijo za delo. Do podobne ugotovitve smo prišli tudi pri pogostosti uporabe oblik ocenjevanja, ki ne temeljijo na vrednotenju odgovorov. Pri ocenjevanju znanja se pokaže, da učiteljice pogosteje ocenjujejo znanje $z$ vrednotenjem odgovorov kot $z$ drugimi oblikami ocenjevanja. To sicer ni najbolj vzpodbuden rezultat, je pa pričakovan, saj si drugačne oblike ocenjevanja (ocenjevanje izdelkov, postopkov, portfolija ipd.) šele vtirajo pot $\mathrm{v}$ stalno učno prakso. Temu pritrjujejo tudi rezultati raziskave, ki sta jo opravili Dolenc Orbanić in Furlan (2015).

Ugotovili smo, da se po priljubljenosti oziroma po oceni lastne kompetentnosti za poučevanje učni predmet spoznavanje okolja uvršča nekoliko nad povprečje priljubljenosti učnih predmetov $\mathrm{v}$ prvem vzgojno-izobraževalnem obdobju. Z rezultatom smo lahko zadovoljni, ni pa z njim moč pojasniti odklonilnega odnosa naših četrtošolcev in njihovih staršev do naravoslovja, ki ga je razkrila raziskava TIMSS 2015 (Pavešić in Svetlik, 2016).

Ugotovili smo, da večina učiteljic izvaja pouk v naravi več kot 5-krat na leto, v različnih kulturnih in izobraževalnih ustanovah manj kot 5-krat na leto, $\mathrm{v}$ računalniški učilnici pa manj kot 2-krat na leto. Glede na didaktična priporočila $\mathrm{v}$ učnem načrtu za učni predmet spoznavanje okolja (Kolar idr., 2011) bi moral pouk pogosteje potekati izven matične učilnice. Temu pritrjujejo tudi ugotovitve raziskave, ki jo je opravila Rajšp s sodelavci (2013), da pogostejše izvajanje pouka v naravnem okolju pozitivno vpliva na naravoslovno znanje. 
V povezavi s pogostostjo izvajanja različnih aktivnosti smo ugotovili, da učiteljice redkeje kot druge aktivnosti izvajajo aktivnosti, ki vključujejo povezovanje in interpretacijo ter urejanje in analizo podatkov. Podobno velja za aktivnosti, ki vključujejo preproste raziskave ter uporabo IKT in e-gradiv. Tudi ta rezultat ni presenetljiv, saj gre pri delu s podatki za kognitivno, pri izvajanju raziskav in uporabi IKT pa za tehnično in organizacijsko zahtevnejše aktivnosti. Manj pogosta uporaba IKT se ujema z ugotovitvijo, da učiteljice redko izvajajo pouk v računalniški učilnici. Glede na ugotovitve raziskave, ki jo je opravila Cotič s sodelavci (2019), lahko upravičeno domnevamo, da bi pogostejše izvajanje omenjenih aktivnosti pozitivno vplivalo na dvig naravoslovne pismenosti.

\section{Doprinos raziskave in njene omejitve}

Namen raziskave je bil osnovni pregled izvajanja učnega predmeta spoznavanja okolja v prvem vzgojno-izobraževalnem obdobju, zato raziskava ne daje natančnega vpogleda v obravnavano problematiko in tudi ne ponuja nobenih konkretnih rešitev. Kljub temu so lahko ugotovitve pričujoče raziskave izhodišče za načrtovanje obširnejših in bolj poglobljenih raziskav. Pri vrednotenju doprinosa raziskave ne gre pozabiti, da je zaradi neslučajnostnega vzorca možnost oblikovanja sklepov in upravičenost posploševanja ugotovitev omejena.

\section{Nadaljnje možnosti za raziskovanje}

Nadaljnje raziskovanje bi bilo smiselno usmeriti v iskanje razlogov za manj pogosto uporabo določenih načinov ocenjevanja, za manj pogosto izvajajo določene aktivnosti in večjo oziroma manjšo priljubljenost določenih tem. $V$ ta namen bi bilo treba uporabiti druge tehnike zbiranja podatkov, kot so intervju, fokusne skupine, opazovanje. V prihodnjih raziskavah bi bilo smiselno podrobneje raziskati vpliv različnih dejavnikov na naravoslovni kapital učencev. Prav zato bi bilo treba razviti instrument za merjenje naravoslovnega znanja posameznega učenca. 


\section{Summary}

In the second half of the last century, there was already a strong perception of natural science as a subject which was widely discussed not just amongst engineers and scientists, but, to an extent, by everyone, if they wanted to successfully cope with challenges of the modern era. The emphasis then moved to the idea that knowledge and understanding of certain facts was not enough on its own. Despite the growth of knowledge, and its role in learning processes, procedures and opinions, as well as relevant changes in the teaching system, scientists observed that this was still insufficient to engage individuals successfully with the world of natural sciences. With the reforms made in the US educational system at the end of the 1980s, knowledge of natural science is now referred to as natural science literacy. This concept is based on the notion that the modern society needs educated "users", who can think, or "owners" of knowledge in natural science - in other words, scientifically literate individuals. Recent research findings on distinctions in natural science engagement in the adult life in the British population showed that natural science literacy is not, in itself, a guarantee of an active engagement in natural science within society.

In connection with the active use of natural science, the concept of natural science capital of an individual is becoming more and more established, which, according to the social, cultural and economic capital model, including natural science knowledge, experiences and resources that the individual has acquired. Research shows though, that the school's influence on students' natural science capital is limited, but nevertheless important. Balanced development of all areas of natural science capital requires a well-trained and motivated teacher who is an expert in different areas of study, actively involves students in learning, using different methods and teaching environments, developing various cognitive processes and examining and evaluating their knowledge in different ways. Detailed teaching of the subject learning about the environment in Slovenia has not been carefully studied, but the results of the international TIMMS 2015 study may be of help to us. In this paper, we present in more detail the course and results of the research, in which we were primarily interested in the teachers' profile in the 1st trimester of the elementary school and what methods of teaching and assessment of knowledge are used by those teachers during the learning process of the environment and to what extent. We were also interested in what their attitude is towards individual thematic clusters. Based on 
quantitative analysis of the collected material, we present some of the most important findings.

We have come to the conclusion that the teachers' experience and the class they have been assigned to do not influence the teachers' motivation to work. We have come to a similar conclusion regarding the frequency of the different methods of knowledge assessment that are not based on the evaluation of students' answers. The knowledge assessment rather shows that the teachers prefer to assess the students' knowledge with the evaluation method rather than with other assessment methods. That is not an encouraging result but it is an expected one, as other ways of examining knowledge are only paving their way to become incorporated into the learning practice. In endorsing increasing knowledge of natural science, we should aspire to more knowledge assessment methods that are not based on evaluating students' answers.

We have concluded that in terms of popularity, expressed by the teacher's own estimation of their competency to teach a specific course, music was placed in last position, while introduction to environmental science falls a little above average. We are pleased with the result because we were especially interested in the field of environmental science. However, this result fails to further explain the conclusions of the international TIMMS 2015 study, which shows that our students have taken a more negative stance to natural science in comparison to their peers from other countries.

With regard to the frequency of carrying out different activities, we discovered that the teachers employ the following activities less than others, namely connecting, interpreting, organising and analysing data by carrying out simple research and using ICT and e-learning. This result is not surprising either, because working with data is considered as an advanced cognitive skill, while carrying out research and application of ICT are considered as technically and organisationally advanced activities. We assume that the higher frequency of the activities mentioned above would positively affect the increase of knowledge in natural science. 
We discovered that classes which introduce environmental science are delivered in natural enivironment very frequently, however teachers less frequently take their students to cultural and educational institutions and even are even less likely to make use of computer classrooms. This study has given us a good overall view of the running of introduction to environmental science during the early school years and has also established a good platform for the future planning of new expanded and in-depth research in this field.

\section{Literatura}

Archer, L., DeWitt, J. in Willis, B. (2014). Adolescent boys' science aspirations: Masculinity, capital, and power. Journal of Research in Science Teaching, 51, 1-30.

Archer, L., Dawson E., DeWitt, J., Seakins, A. and Wong, B. (2015). "Science Capital": A Conceptual, Methodological, and Empirical Argument for Extending Bourdieusian Notions of Capital Beyond the Arts. Journal of Research in Science Teaching, 52(7), 922-948.

Cotič, N., Zuljan, D., Plazar, J. (2019). Vpliv uporabe IKT in iə̌kustvenega ǔcenja na mnenje vǐencev o naravoslovnem dnevu na morski obali, Revija za elementarno izobraževanje, 12(1), 27-43.

Delors, J., Al Mufti, I., Amagi, I., Carneiro, R., Chung, F., Geremek, B., Gorham, W., Kornhauser Frazer, A., Manley, M., Quero, M. P., Savané, M., Singh, K., Stavehagen, R., Suhr, M. W., Nanzhao, Z. (1996). Učenje - skriti z̧aklad: Poroüilo Mednarodne komisije o izobraževanju za 21. stoletje, pripravljeno za UNESCO. Ljubljana: MŠŠ.

Gardner, P. L. (1975). Attitudes to Science. Studies in Science Education, 2(1), 1-41.

Harlen, W., Qualter, A. (2010). The Teaching of Science in Primary Schools. New York: Routledge.

Kolar, M., Krnel, D in Velkavrh, A. (2011). Uǐni nǎrrt, program osnovna šola, predmet Spoznavanje okolja. Ljubljana: MSŠ in ZRSŠ.

Pavešić, B. J. in Svetlik, K. (2016). Znanje matematike in naravoslovja med četrtošolci v Sloveniji in po svetu: iæsledki raziskave TIMSS 2015. Ljubljana: Pedagoški inštitut.

Polak A., Devjak, T., Cenčič, M. (2005). Predstavitev nekaterih rezultatov raziskave projekta partnerstvo fakultet in šol o modelu nadaljnjega izobraževanja in usposabljanja. V: Devjak, T. (ur.), Partnerstvo fakultete in vagojnoizobra ̌̌evalnih zavodov. Izobrą̌evanje - praksa - rą̧iskovanje (pp. 151-178). Pedagoška fakulteta, Ljubljana.

Pevec, M. (2012): Programi nadaljnjega izobraževanja in usposabljanja učiteljev kot dejavnik profesionalnega razvoja, Revija za elementarno izobraževanje, 5(2-3), 167-182.

Petek, D. (2012): Zgodnje učenje in poǔevanje naravoslovja z raziskovalnim pristopom, Revija za elementarno izobraževanje, 5(4), 101-114.

OECD (2017). PIS A 2015 Assessment and Analytical Framework: Science, Reading, Mathematic, Financial Literacy and Collaborative Problem Solving, revised edition. Paris: OECD Publishing.

Rajšp, M., Pintarič, N. in Fošnarič, S. (2013). Načrtovanje in izvajanje obravnave žviljenjskih prostorov v naravi, Revija za elementarno izobraževanje, 6(4), 87-103.

Raper, G. and Stringer, J. (1991). Encouraging Primary Science. London: Cassel Publishers.

Rutherford, F. J. and Ahlgren, A. (1991). Science for All Americans: Education for a changing future. Oxford: Oxford University Press.

SI-STAT (2018). Podatkovna baza. Ljubljana: Statistični urad Republike Slovenije.

Skribe Dimec, D. (2013). Diferenciacija pri poučevanju naravoslovja v prvem in drugem vagojno-ižobraževalnem obdobju osnovne šole, Revija za elementarno izobraževanje, 6(2-3), 193-211.

UNESCO (2012). International Standard Classification of Education (ISCED 2011). Montreal: UNESCOIUS. 


\section{Avtor}

\section{Vasja Kožuh}

podiplomski študent, Univerza na Primorskem, Pedagoška fakulteta, Cankarjeva 5, 6000 Koper Slovenija in glavni urednik izobraževalnega založništva, DZS, Dalmatinova 2, 1358 Ljubljana Slovenija, e-pošta: vasja.kozuh@siol.net

postgraduate student, University of Primorska, Faculty of Education, Cankarjeva 5, 6000 Koper Slovenija and Editor-in-Chief, DZS Publishing, Dalmatinova 2, 1358 Ljubljana Slovenija, e-mail: vasja.kozuh@siol.net 